\title{
Insights into Bullying and Verbal Aggressiveness through Social Network Analysis
}

\author{
Alexandra Bekiari, Vasiliki Pachi \\ Faculty of Physical Education and Sports Sciences, University of Thessaly, Trikala, Greece \\ Email: sandrab@pe.uth.gr
}

How to cite this paper: Bekiari, A. and Pachi, V. (2017) Insights into Bullying and Verbal Aggressiveness through Social Network Analysis. Journal of Computer and Communications, 5, 79-101.

https://doi.org/10.4236/jcc.2017.59006

Received: June 4, 2017

Accepted: July 4, 2017

Published: July 7, 2017

Copyright $\odot 2017$ by authors and Scientific Research Publishing Inc. This work is licensed under the Creative Commons Attribution International License (CC BY 4.0).

http://creativecommons.org/licenses/by/4.0/

\begin{abstract}
Aim of this research is to reveal social structures, typologies and determinants of verbal aggressiveness and bullying. Five students' networks from various Higher Education departments in Thessaly, Greece (Physical Education, Veterinary, Business Administration) (total nodes $\mathrm{N}=245$ ) have been examined by Social Network Analysis and conventional statistics in 2017. Main results: Rudeness relations are denser at the Physical Education department due to the intensity and pressure of corporal exercise. Social exclusion seems to be much more common practice. Hurting necessitates particularly intensive conditions while deriding, rudeness and threatening are compatible with any action of bullying. The offenders tend to practice simultaneously bullying and verbal aggressiveness but often against different targets. Various levels of victimization are diagnosed through selectiveness in strategies of offense. Obesity often constitutes a reason of depreciation. Education values stimulate respectfulness rather than aggressive jealousness. Ambitiousness, travelling experience, social selectiveness based on criteria of intellectual, encyclopedic qualifications or politeness also prevent verbal aggressiveness. Female students seem to be more invulnerable. Bullying seems to be reciprocal and diachronic. Verbal aggressiveness seems to conceal a presumption of corporal aggressiveness. Especially, ambitiousness in the scientific arena or the high education level of father seems to encourage practicing verbal aggressiveness.
\end{abstract}

\section{Keywords}

Bullying, Verbal Aggressiveness, Social Network Analysis

\section{Introduction}

\subsection{Bullying}

Bullying refers to the combination of violent actions against a person, which are 
repeatedly taken by one or more subjects and is ranging from slight teasing to serious collective violence [1] [2]. It's about an aggressive behavior in which there must be an imbalance in the power relationship among peers because of social, emotional and physical differences [1] [2] [3]. Bullying is abuse of power [4]. A more powerful person intends to cause distress or harm and attacks with words, physical contact or obscene gestures, and intentional exclusion from a group a less powerful one who is not able to defend himself against these actions [1] [5]. As bullying is known to exist at schools and workplaces, it is reasonable to assume that universities cannot be exempt from it either. In the context of higher education, the motive for bullying may be age, sexuality, ethnic origin or handicap [6]. According to the Student Experience Report (2008), 7\% of British higher education students had been bullied, and women students had experienced it more often than men. It seems that due to its history and special characteristics, academia is an arena that is highly vulnerable to bullying and inappropriate behavior [7] [8] [9]. [10] identified that teenage boy bullies had an antisocial personality combined with physical strength and victims had an anxious personality pattern combined with physical weakness. Shame and fear are strongly attached to the victim's role [9] [11] [12]. Campus bullying behavior includes malicious bullying, hurt and devastating violence. According to the research by [13], about $70 \%$ students committed verbal attacks against others, but only few students committed other harmful attacks (about 1.5\%). Verbal bullying is more usual than physical bullying [14] [15]. The occurrence of bullying at school often constitutes a barrier for young people preventing them from evolving into well-adjusted adults [16]. Campus bullies may form a habit and continue to bully others on occasions outside the campus, and finally may commit a crime [17] [18]. Victims of bullying may be plagued with chronic feelings of loneliness, anxiety, depression, general health complaints, and diminished academic participation and achievement. Coupled with suicidal thoughts in both bullies and victims, bullying is seen as a major cause of other serious problems, such as criminal acts and alcohol abuse [10] [19] [20] [21] [22]. Moreover [23] pointed out that the likelihood for children who were once bullied at schooling age committing severe crimes is five times more than of those who were not. When bullying occurs, it tends to be long-standing. [7] found $21 \%$ of their samples reported bullying that had persisted for more than five years in duration and this percentage increased to $49 \%$ when they focused on faculty.

\subsection{Verbal Aggressiveness}

Verbal aggressiveness is conceptualized as a message behavior that attacks an individual's self-concept to deliver psychological pain and to make the person feel less favorable about himself [24] [25]. There are ten different types of verbally aggressive messages such as competence attacks, character attacks, background attacks, physical appearance attacks, malediction, teasing, ridicule, threats, swearing, and nonverbal emblems [26]. Verbal aggressiveness is destructive for the relationships [27] [28] [29] [30] and, if it is regularly directed toward a per- 
son, it may constitute psychological abuse [31]. The verbal aggressiveness appears to be positively related to narcissism, natural aggression, anger [32], Machiavellian beliefs [33] [34], autocratic style and anxiety [35] [36]. Otherwise, it is negatively associated with emotional learning [37] [38] [39], interpersonal attraction [40] [41] [42], internal motivation and internal reasons for discipline [43]-[48], motivation climate with emphasis on learning [49], fair play [50], and receivers perception of instructor's credibility [51] [52]. The profile of verbally aggressive individuals is characterized by low emotional stability and high levels of anger [53]. Verbally aggressive university students appear to be less satisfied with their working teams, less flexible from cognitive and communicative point of view. They also are characterized by lower levels of self-confidence and by increased jealousy towards the non-verbally aggressive students [52] [54] [55].

\subsection{Innovation}

Although several social network analyses have already taken place focusing on aggressiveness and bullying [56]-[64], the academic added value of this research consists in the application of social network analysis in university students classes at various faculties (veterinary, physical education, business administration). Namely, it is a cross-disciplinary network analysis. Apart from that, in this research the relation between bullying and verbal aggressiveness is endeavored. The practical added value of this research consists in the detection of non-network (personal-social) characteristics which are determinants of the bullying and verbal aggressiveness. This is expected to be helpful for the instructors to estimate the susceptibility of students to such behavior.

\section{Method}

From 2016 to 2017, five students classes Higher Education departments of Thessaly, Greece, have been selected as network samples. This sample size was a feasible one. The students were selected so as to belong to a possibly wide range of semesters. The $60 \%$ of students originated from urban areas and the $40 \%$ from semi-rural and rural areas. Specifically, these samples were: two classes of the department of Veterinary $\left(\mathrm{N} 1=66\right.$ of the $4^{\text {th }}$ semester-female $=43$, male $=$ $23, \mathrm{~N} 2=53$ of the $8^{\text {th }}$ semester-female $=32$, male $\left.=21\right)$, two classes of the department of Physical Education and Sport Sciences (N3 $=57$ of the $4^{\text {th }}$ semesterfemale $=28$, male $=29, \mathrm{~N} 4=42$ of the $8^{\text {th }}$ semester-female $=23$, male $=19$ ) at the University of Thessaly and a class of the Department of Business Administration, Technological Educational Institute of Thessaly (N5 $=27$ of the $6^{\text {th }}$ semester-female $=14$, male $=13$ ). Thus, the total sample consisted of 245 nodes. This sample presents the advantage of the variability of study time (measured in semester) and the variability of characteristics required at Veterinary, Physical Education and Business Administration in terms of corporal qualification. If the research was focusing only on the department of Physical Education, this could be regarded as biased, because Physical Education could be considered to be a field quite susceptible to verbal aggressiveness or even bullying due to its specific 
content and context (namely, corporal force and competitiveness in sport games).

Furthermore, the additional departments were Veterinary and Business Administration due to their mentality variability. Veterinary necessitates higher admission standards than Physical Education. Business Administration cultivates organizational, cultural and social discourse which could be supposed to "refine" the everyday communication and mitigate verbal aggressiveness and bullying. Thus, the whole sample is not so biased as it would be, if it consisted only of Physical Education students. Apart from that, although it is a judgment sample and not a random one, this is not a weakness as it aims at analytic and not descriptive statistics. Simultaneously, research ethics rules were observed and discretion was guaranteed in order to convince the participants to give sincere answers.

The network-related part of the questionnaire was based on previous tested questionnaires [57] [65] [66]. Questions relevant to verbal aggressiveness and bullying were converted from psychometric into network form. The non-network part of questionnaire contained parameters concerning the personal profile of students (e.g. age, gender, socio-economic state).

Network variables such as indegree, Katz status, pagerank, authority and outdegree, were calculated using Visone 1.1. These multiple variables were used in order to enable a multiple structural exploration. Conventional statistics (crosssectional analysis with Spearman test) has been implemented aiming at detecting correlations between network and non-network variables effacing the outliers effect. Such a bivariate analysis was preferred to a multivariate one, because it enables an overview on all possible relations [67] [68] [69]. Principal Component Analysis was also implemented in order to reveal behavioral patterns (typology).

\section{Results and Discussion}

In "Figure 1" (Physical Education department), targeting for rudeness and social exclusion are analyzed as hierarchies (nodes who are mostly targeted are at the top of the pyramids of the three hierarchical algorithms, Katz, Pagerank and Authority) are presented. It is remarkable that more than one summit appear in the rudeness hierarchy in all three algorithms. Particularly, the authority pyramid is almost upside down. So anomalous pyramids of rudeness targeting do not appear in the other two departments ("Figure 2" and "Figure 3"). This can be understood as a result of the subject of this department. Exercises in Sport and Physical Education often are characterized by intensive competition and pressure. This often leads to outbursts which are perceived as rudeness. Thus, more than one student are targeted during exercise. Moreover, the network of rudeness relations seems to be much more dense in the Physical Education (1.7\%) department than in the other two departments $(0.3 \%$ in Veterinary and $0.9 \%$ in Business Administration). This is also understandable considering the intensity and pressure of the organized exercise. 


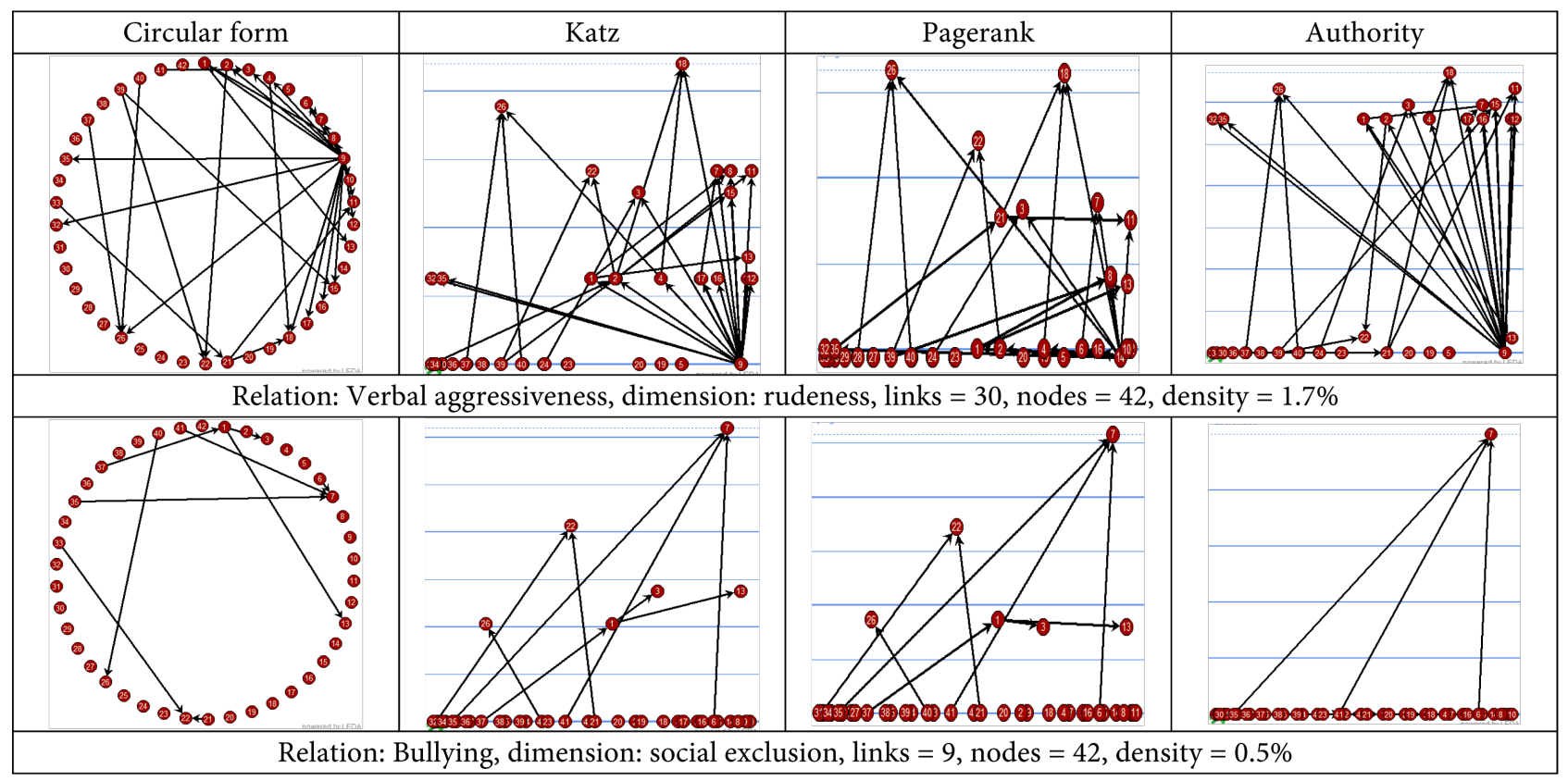

Figure 1. Examples of diagrams at the Dept. of Physical Education and Sports Science, University of Thessaly, Greece.

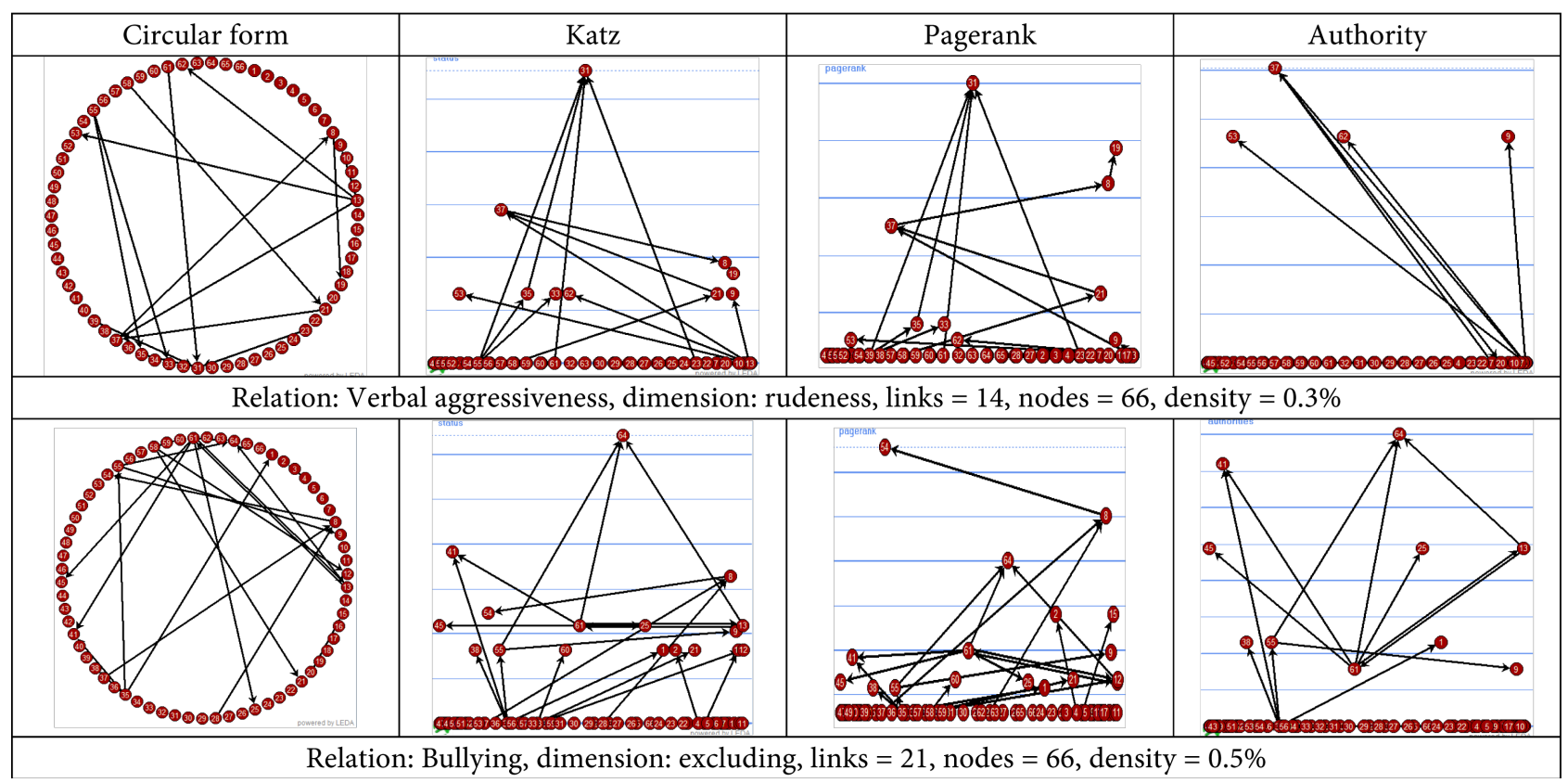

Figure 2. Examples of diagrams at the Dept. of Veterinary, University of Thessaly, Greece.

As for the social exclusion in Physical Education department, this is not extremely different in terms of density or pyramid structure from the other two departments (see "Figure 2" and "Figure 3"). Therefore, social exclusion seems to depend not on the subject of the department but rather on the common mentality characterizing students in every department. Everywhere, there are some persons who try to exclude others from their companionships and, as expected, there are distinct "black sheep" (one distinct summit in every pyramid).

In "Table 1", targeting for hurting mainly seems to run together with being 


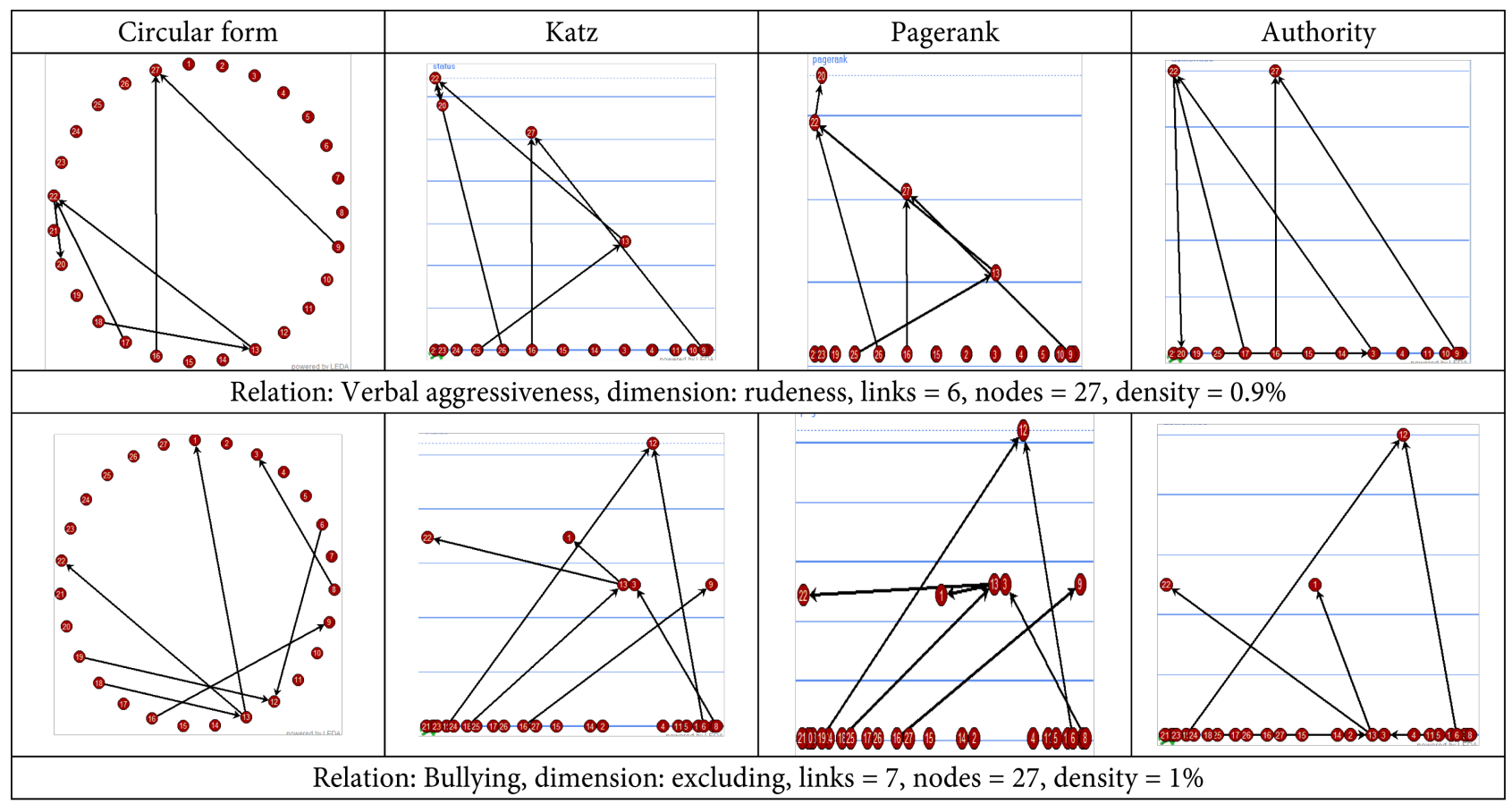

Figure 3. Examples of diagrams at the Dept. of Business Administration, Technological Educational Institute of Thessaly, Greece.

Table 1. Relation between verbal aggressiveness and bullying (targeting) $($ sum $=$ indegree + katz + pagerank + authority).

\begin{tabular}{|c|c|c|c|c|c|}
\hline & hurt.target.sum & deride.target.sum & rude.target.sum & threaten.target.sum & harassment.target.sum \\
\hline \multirow[t]{2}{*}{ exclude.target.sum } & $0.278\left(^{* *}\right)$ & $0.575(* *)$ & $0.611\left(^{* *}\right)$ & $0.471(* *)$ & $0.272(* *)$ \\
\hline & 0.000 & 0.000 & 0.000 & 0.000 & 0.000 \\
\hline \multirow[t]{2}{*}{ rumors.target.sum } & 0.086 & $0.394(* *)$ & $0.603(* *)$ & $0.806\left(^{* *}\right)$ & $0.518\left(^{* *}\right)$ \\
\hline & 0.178 & 0.000 & 0.000 & 0.000 & 0.000 \\
\hline \multirow[t]{2}{*}{ fight.target.sum } & 0.047 & $0.440(* *)$ & $0.530(* *)$ & $0.534\left(^{* *}\right)$ & $\left.0.1611^{*}\right)$ \\
\hline & 0.464 & 0.000 & 0.000 & 0.000 & 0.012 \\
\hline \multirow[t]{2}{*}{ disagreement.target.sum } & -0.040 & $0.376\left(^{* *}\right)$ & $0.412(* *)$ & $0.571(* *)$ & $\left.0.808{ }^{* *}\right)$ \\
\hline & 0.531 & 0.000 & 0.000 & 0.000 & 0.000 \\
\hline \multirow[t]{2}{*}{ encourage.scold. target.sum } & $0.347\left(^{* *}\right)$ & $0.492(* *)$ & $0.562(* *)$ & $0.575(* *)$ & 0.050 \\
\hline & 0.000 & 0.000 & 0.000 & 0.000 & 0.438 \\
\hline \multirow[t]{2}{*}{ deny.help.target.sum } & $0.164\left(^{*}\right)$ & $0.453(* *)$ & $0.478\left(^{* *}\right)$ & $0.548\left(^{* *}\right)$ & $0.272(* *)$ \\
\hline & 0.010 & 0.000 & 0.000 & 0.000 & 0.000 \\
\hline \multirow[t]{2}{*}{ fun.target.sum } & $0.254\left(^{* *}\right)$ & $0.750(* *)$ & $0.625\left(^{* *}\right)$ & $0.514\left(^{* *}\right)$ & $0.365\left(^{* *}\right)$ \\
\hline & 0.000 & 0.000 & 0.000 & 0.000 & 0.000 \\
\hline \multirow[t]{2}{*}{ unhappiness.target.sum } & 0.101 & $0.422(* *)$ & $0.622(* *)$ & $0.760\left(^{* *}\right)$ & $0.495^{(* *)}$ \\
\hline & 0.116 & 0.000 & 0.000 & 0.000 & 0.000 \\
\hline
\end{tabular}

${ }^{* *}$ Correlation is significant at the 0.01 level (2-tailed). ${ }^{*}$ Correlation is significant at the 0.05 level (2-tailed). 
encouraged for scolding. This is understandable, as long as the intensive involvement in scolding is conducive for being hurt while other forms of bullying (simple exclusion, rumors dissemination, fight etc.) are not so strongly connected with hurting. Thus, hurting necessitates particularly intensive conditions. Deriding, rudeness and threatening seem to noticeably accompany all dimensions of bullying. Thus, these three dimensions of verbal aggressiveness are compatible with any action of bullying. These three dimensions are quite common expressive forms for deconstructing social relations and devalue the target person.

Finally, exclusion, fight, scolding and denying help do not seem to be so harassing. Certain other forms of bullying such as rumors dissemination, disagreements, targeting for fun and unhappiness seem to be conducive for harassment.

In contrast to "Table 1", where the targets seem to attract particular combinations of bullying and verbal aggression (e.g. hurting and encouraging to scold, harassment with rumors, disagreements, fun and unhappiness), in "Table 2", so few and distinct combinations are not appear. Verbal aggression and bullying seems to be practiced by each offender quite simultaneously (almost all dimensions of verbal aggressiveness are strongly correlated with almost all dimensions of bullying). The one who is verbally aggressive tends also to practice bullying. The fact, however, that there more restricted and distinct combinations of receiving verbal aggression and bullying in "Table 1" shows that the offenders

Table 2. Relation between verbal aggressiveness and bullying (practicing).

\begin{tabular}{|c|c|c|c|c|c|}
\hline & hurt_outdegree & deride_outdegree & adressed_rudely_outdegree & threaten_outdegree ha & arassment_outdegree \\
\hline \multirow[t]{2}{*}{ make_fun_outdegree } & $0.511(* *)$ & $0.652(* *)$ & $0.723(* *)$ & $0.629\left(^{* *}\right)$ & $0.386\left(^{* *}\right)$ \\
\hline & 0.000 & 0.000 & 0.000 & 0.000 & 0.000 \\
\hline \multirow[t]{2}{*}{ exclude_outdedgree } & $0.414(* *)$ & $0.504(* *)$ & $0.558(* *)$ & $0.361\left(^{* *}\right)$ & $0.529\left(^{* *}\right)$ \\
\hline & 0.000 & 0.000 & 0.000 & 0.000 & 0.000 \\
\hline \multirow[t]{2}{*}{ spread_rumors_outdegree } & $0.252(* *)$ & $0.353(* *)$ & $0.333(* *)$ & $0.374(* *)$ & $0.516(* *)$ \\
\hline & 0.000 & 0.000 & 0.000 & 0.000 & 0.000 \\
\hline \multirow[t]{2}{*}{ fight_outdegree } & $0.450(* *)$ & $0.482(* *)$ & $0.426(* *)$ & $0.377(* *)$ & $0.200(* *)$ \\
\hline & 0.000 & 0.000 & 0.000 & 0.000 & 0.002 \\
\hline \multirow[t]{2}{*}{ disagreements_outdegree } & $0.450(* *)$ & $0.436(* *)$ & $0.474(* *)$ & $0.360(* *)$ & $0.336(* *)$ \\
\hline & 0.000 & 0.000 & 0.000 & 0.000 & 0.000 \\
\hline \multirow[t]{2}{*}{ encourage_to_scold_outdegree } & $0.337(* *)$ & $0.158\left(^{*}\right)$ & 0.123 & $0.233(* *)$ & $0.181(* *)$ \\
\hline & 0.000 & 0.013 & 0.055 & 0.000 & 0.004 \\
\hline \multirow[t]{2}{*}{ deny_help_outdegree } & $0.348(* *)$ & $0.385(* *)$ & $\left.0.377^{* *}\right)$ & $0.266(* *)$ & $0.326(* *)$ \\
\hline & 0.000 & 0.000 & 0.000 & 0.000 & 0.000 \\
\hline \multirow[t]{2}{*}{ unhappiness_outdegree } & $0.543(* *)$ & $0.503(* *)$ & $0.548(* *)$ & $0.424(* *)$ & $0.572(* *)$ \\
\hline & 0.000 & 0.000 & 0.000 & 0.000 & 0.000 \\
\hline
\end{tabular}

${ }^{* *}$ Correlation is significant at the 0.01 level (2-tailed). ${ }^{\star}$ Correlation is significant at the 0.05 level (2-tailed). 
tend to practice simultaneously bullying and verbal aggressiveness but often against different targets. E.g., in "Table 1", the one who is hurt, is not necessarily offended by fight (.464 in sign). However, in "Table 2", (.450 sign.) the offender who hurts, also causes fights. This is understandable, only if it is accepted that the offender practices both these actions but against different targets (otherwise, the indegrees correlations in "Table 1", would almost all be significant, like in “Table 2").

\section{Correlations}

In "Table 3", four types of target: a) The "fully offended" is a person victimized in all possible ways of verbal aggression and bullying. It looks the most "tragic" profile of victim. b) The "harassed by bullying" is a particular target that seems to be vulnerable only to certain combination (strategy) of offense. In this case, certain bullying forms (cause unhappiness, disseminate rumors and encourage to scold) seem to become tools for verbally harassing him or for enhancing this harassment. This is a much more selective strategy of offending than the strategy followed against the "fully offended". c) The target who is "hurt by bullying" is also the victim of a quite selective strategy consisting only in using exclusion (from companionship) and fight in order to verbally hurt or to enhance this hurting. d) The "just excluded" is the most selectively offended target. He is only excluded from companionship without being offended verbally or in any other way.

Thus, the four types of targets mentioned above express four strategies of offending which appear to be more and more selective (from "fully offended" to

Table 3. Typology of verbal aggressiveness and bullying (targeting) (sum = indegree + katz + pagerank + authority).

\begin{tabular}{|c|c|c|c|c|c|}
\hline & & $\begin{array}{c}\text { Fully } \\
\text { offended }\end{array}$ & $\begin{array}{c}\text { Harassed by } \\
\text { bullying }\end{array}$ & $\begin{array}{l}\text { Hurt by } \\
\text { bullying }\end{array}$ & Just excluded \\
\hline \multirow{5}{*}{ 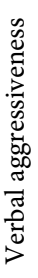 } & hurt.target.sum & 0.448 & -0.446 & 0.394 & 0.042 \\
\hline & deride.target.sum & 0.523 & -0.294 & -0.466 & 0.178 \\
\hline & rude.target.sum & 0.693 & -0.334 & -0.185 & 0.126 \\
\hline & harassment.target.sum & 0.639 & 0.623 & -0.097 & -0.011 \\
\hline & threaten.target.sum & 0.797 & -0.078 & -0.154 & -0.107 \\
\hline \multirow{8}{*}{ 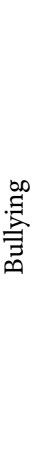 } & fun.target.sum & 0.785 & -0.325 & -0.122 & 0.115 \\
\hline & unhappiness.target.sum & 0.521 & 0.387 & -0.386 & 0.139 \\
\hline & exclude.target.sum & 0.446 & 0.182 & 0.492 & 0.565 \\
\hline & rumors.target.sum & 0.306 & 0.656 & 0.247 & 0.147 \\
\hline & fight.target.sum & 0.496 & -0.042 & 0.403 & -0.624 \\
\hline & disagreements.target.sum & 0.736 & -0.118 & 0.135 & -0.267 \\
\hline & encourage.scold.target.sum & 0.426 & 0.388 & -0.172 & -0.385 \\
\hline & deny.help.target.sum & 0.582 & -0.065 & 0.267 & 0.175 \\
\hline
\end{tabular}

Extraction Method: Principal Component Analysis, 4 components extracted. 
"just excluded"). This gradual selectiveness respectively creates a variety of victimization patterns, ranging from quite "severe" like the "fully offended" (which seems to be a socially pathological case of marginalization) to quite "light" ones like the "just excluded" (which may even be regarded as normal, as none is welcome in all companionships). Thus, a fluctuating grade of victimization is diagnosed though this typology, where the severity of the marginalization is a matter of selectiveness in the strategy of offending.

In "Table 4", the respective strategies of offending are depicted. a) Just as in "Table 3" the "fully offended" target depicts the strategy of making someone an absolute victim, so in "Table 4" the strategy of being "fully offensive" is also depicted. However, a "fully offensive" type uses all possible forms of verbal aggression and bullying but he does not necessarily implement all these on the same target (as it is also argued in the comparative analysis between "Table 1" and "Table 2"). b) The "harassing by bullying" is roughly respective to the "harassed by bullying" described in "Table 3". However, the "harassing by bullying" does not use encouraging scolding but only exclusion and dissemination of rumors in order to harass or to make harass more painful. c) The "just bullying" type is quite selective in his behavioral patterns. He only denies helping. This is the most discrete and possibly the most peaceful or least provocative strategy to offend someone. d) Finally, the "just verbal aggressive" type confines his strategy on deriding, which is a quite simplified form of verbal aggression in terms of social conflict (no big turbulence is caused).

Just as in "Table 3", so in "Table 4" a gradual selectiveness in offensive strategy is observed, varying from "fully offensive" to "just bullying" and "just verbal aggressive". Thus, the grade of offensiveness is also a matter of selective-

Table 4. Typology of verbal aggressiveness and bullying (practicing).

\begin{tabular}{|c|c|c|c|c|c|}
\hline & & $\begin{array}{c}\text { Fully } \\
\text { offensive }\end{array}$ & $\begin{array}{c}\text { Harassing by } \\
\text { bullying }\end{array}$ & $\begin{array}{c}\text { Just } \\
\text { bullying }\end{array}$ & $\begin{array}{l}\text { Just verbal } \\
\text { aggressive }\end{array}$ \\
\hline \multirow{5}{*}{ 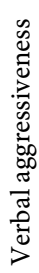 } & hurt_outdegree & 0.718 & -0.424 & 0.223 & -0.062 \\
\hline & deride_indegree & 0.372 & -0.007 & 0.053 & 0.785 \\
\hline & adressed_rudely_outdegree & 0.671 & -0.140 & -0.321 & 0.016 \\
\hline & threaten_outdegree & 0.691 & -0.130 & -0.455 & 0.014 \\
\hline & harassment_outdegree & 0.629 & 0.396 & -0.280 & 0.213 \\
\hline \multirow{8}{*}{ 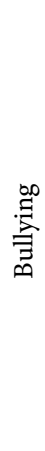 } & make_fun_outdegree & 0.764 & -0.285 & -0.332 & 0.063 \\
\hline & unhappiness_outdegree & 0.702 & 0.135 & 0.176 & 0.149 \\
\hline & exclude_outdedgree & 0.592 & 0.621 & -0.037 & -0.194 \\
\hline & spread_rumors_outdegree & 0.593 & 0.597 & 0.018 & -0.308 \\
\hline & fight_outdegree & 0.586 & -0.380 & 0.077 & -0.297 \\
\hline & disagreements_outdegree & 0.770 & -0.143 & 0.185 & -0.008 \\
\hline & encourage_to_scold_outdegree & 0.580 & -0.165 & 0.276 & -0.326 \\
\hline & deny_help_outdegree & 0.485 & 0.147 & 0.656 & 0.230 \\
\hline
\end{tabular}

Extraction Method: Principal Component Analysis, 4 components extracted. 
ness in strategies. Similar typologies have been proposed in previous research [70] [71] [72] [73].

In "Table 5", several non-network variables appear to be relevant for becoming a target of verbal aggressiveness. As for the physical situation, particularly the weight, the heavier one is, the more he becomes a target of rudeness or threatening. This can be attributed to the fact that obesity and in general, not slim body, often constitutes a reason of depreciation.

The family background, particularly the high education level of parents, seems to play a role protective against verbal aggressiveness. This shows that the students community is dominated by a certain education-related value system, even projected to the family background. The relevance of the education-related values to the anticipation or mitigation of verbal aggressiveness is further supported by the findings concerning general grade. The higher it is, the more it discourages the verbal aggressiveness. Thus, the academic performance seems to stimulate respectfulness rather than aggressive jealousness. On the contrary, failing in too many lessons encourages verbal aggressiveness. Simultaneously, students of higher semesters tend to be more protected against aggressiveness. This can be a result of the fact that older students are more respected by the others.

Additionally to the afore-mentioned education-related value system, the ambitiousness seems also to be respected and thus, discouraging verbal aggressiveness. The desire of distinction either in the scientific or professional arena makes the ambitious person more immune against verbal aggressiveness. A complementary result to these mentioned above, is also the protective function of the experience acquired abroad through traveling in general or for sport reasons. Traveling is not only supposed to constitute someone a distinct "connector" between different cultures and systems but also a recognized leading person. Non-traveling constitutes someone more devalued and marginal and therefore, vulnerable to verbal aggressiveness.

If someone tends to be socially selective, particularly selecting friends based on criteria of intellectual and encyclopedic qualifications, then he achieves to avoid verbal aggressiveness. This is understandable, as a companion selected based on such criteria follows behavioral patterns driven by mental values.

The findings of "Table 5" are to large extent supported in "Table 6". The physical situation appears to play a preventive role also against bullying. As expected, female students seem to be more invulnerable, especially against triggering of provocative disagreements. On the other hand, the deviant physical appearance such as too tall or too heavy tend to be excluded from companion or help or even to be implicated into scold. The high family background in terms of parents education level, seems also to prevent bullying and gain respectfulness once again. The same applies also in the case of general grade in the studies, traveling and ambitiousness.

The general involvement in bullying, namely not only being a target of cyber bullying (according to self-assessment) but also practicing cyber bullying, seems 
Table 5. Non-network determinants of becoming a target of verbal aggressiveness $($ sum $=$ indegree + katz + pagerank + authority).

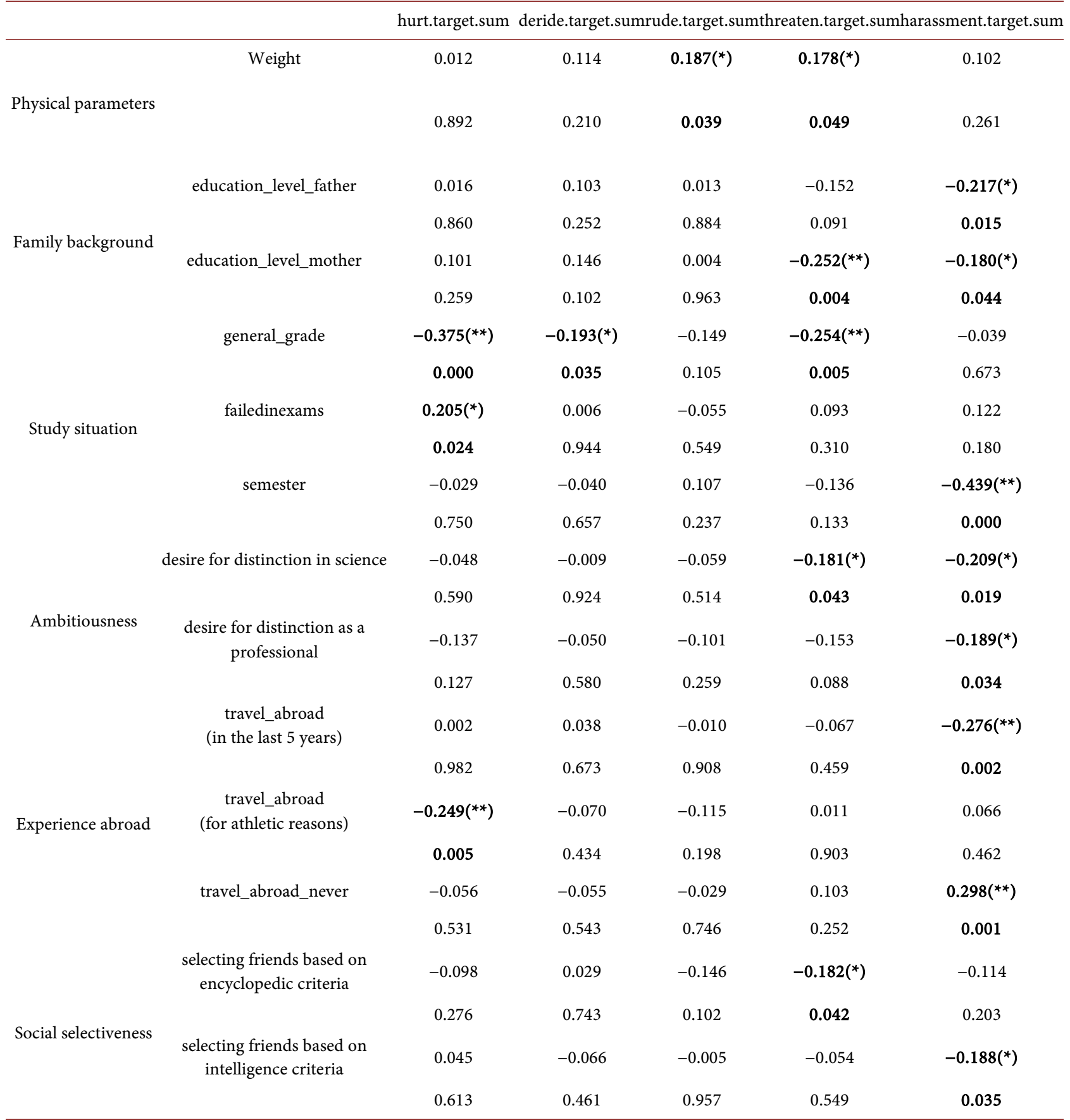

${ }^{*}$ Correlation is significant at the 0.01 level (2-tailed). ${ }^{*}$ Correlation is significant at the 0.05 level (2-tailed).

to constitute someone a target of direct bullying (in terms of rumors, disagreements and exclusion). Thus, bullying presents certain reciprocity. Apart from that, the compatibility of self-assessed cyber bulling with the cross-assessed bullying is an evidence that there is a common perception of bullying among victims and victimizers. Finally, the experience of bullying in childhood seems to be correlated with the bullying one experiences as an adult. Thus, bullying seems to 
be a diachronic pattern of social relation rather than a temporary experience at a particular phase of life. This indicates that there should be stable factors which attract bullying on certain persons.

The selectiveness in companions on the basis of encyclopedic, intellectual and politeness, seem to be protect against causing unhappiness, exclusion, dissemination of rumors and provocative disagreements. This is also understandable, as in Table 5. Meticulously selected friends do not victimize each other and also build a protective social boundary. Similar studies have also taken place in verbal aggressiveness [40] [69].

In "Table 7", practicing verbal aggressiveness seems to be restricted in the case of female or slim students. Thus, practicing verbal aggressiveness depends on physical parameters. In other words, male and heavy students are those who are susceptible to practice verbal aggressiveness. Thus, verbal aggressiveness seems to conceal a presumption of corporal aggressiveness. The high family background (in terms of economic situation) seems also to restrict verbal aggressiveness in terms of hurting but simultaneously it increases threatening. This is an indicator of separation between hurting and threatening. Students originating from rich families are not used to practicing severe forms of verbal aggressiveness. Nevertheless, they desire to enhance their dominance or defense toward others. This separation can be regarded as the classical gap between "theory and practice", "desire and implementation". The travel experience is also a preventive factor against practicing any dimension of verbal aggressiveness. This can attribute not only a potential development of cultural capital and mental superiority but also to a profile of social superiority. This assures a dominance which makes the verbal aggressiveness unnecessary.

However, ambitiousness, particularly the desire of distinction in the scientific arena, seems to encourage verbal aggressiveness, especially in terms of harassment. This shows a tendency to anticipate a prospective social superiority by such a dimension of verbal aggressiveness.

Having experienced or practiced cyber-bullying is correlated with verbal aggressiveness. Particularly, having experienced cyber-bullying seems to make someone more susceptible to rudeness. This can be attributed to the fact that rudeness is an easy reaction aiming at outbalancing past offense or at anticipating a future offense. Those who have practiced cyber-bullying appear to be susceptible to all dimensions of verbal aggressiveness. This shows that cyber-bullying is a space of externalize a much more extensive verbal aggressiveness. Having experienced bullying in childhood seems also to be outbalanced with practicing bullying as an adult student. Thus, bullying is rather characterized by a deep-rooted and diachronic reciprocity.

Finally, the social selectiveness in terms of politeness and intimacy, seems to necessitate not to practice verbal aggressiveness. On the contrary, those who select for friends such persons who are willing to make sacrifices, are susceptible to verbal aggressiveness. Obviously, such a sacrifice is to tolerate their verbal aggressiveness. 
Table 6. Non-network determinants of becoming a target of bullying (sum = indegree + katz + pagerank + authority).

\begin{tabular}{|c|c|c|c|c|c|c|c|}
\hline & & $\begin{array}{l}\text { unhappiness. } \\
\text { target.sum }\end{array}$ & $\begin{array}{l}\text { exclude. } \\
\text { target.sum }\end{array}$ & $\begin{array}{l}\text { rumors. } \\
\text { target.sum }\end{array}$ & $\begin{array}{c}\text { disagreements. } \\
\text { target.sum }\end{array}$ & $\begin{array}{c}\text { encourage. } \\
\text { scold.target.sum }\end{array}$ & $\begin{array}{l}\text { deny.help. } \\
\text { target.sum }\end{array}$ \\
\hline \multirow{6}{*}{ 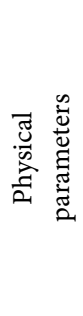 } & \multirow[t]{2}{*}{ Gender } & -0.009 & -0.054 & -0.050 & $-0.133\left(^{*}\right)$ & -0.013 & -0.112 \\
\hline & & 0.894 & 0.399 & 0.440 & 0.037 & 0.841 & 0.079 \\
\hline & \multirow[t]{2}{*}{ Height } & 0.021 & 0.104 & 0.110 & 0.171 & 0.066 & $0.179\left(^{*}\right)$ \\
\hline & & 0.816 & 0.249 & 0.220 & 0.057 & 0.466 & 0.046 \\
\hline & \multirow[t]{2}{*}{ Weight } & 0.022 & $0.214\left(^{*}\right)$ & 0.152 & 0.126 & $0.206\left(^{*}\right)$ & $0.195\left(^{*}\right)$ \\
\hline & & 0.805 & 0.017 & 0.094 & 0.166 & 0.022 & 0.031 \\
\hline \multirow{4}{*}{ 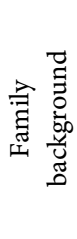 } & \multirow{2}{*}{ education_level_father } & $-0.188\left(^{*}\right)$ & -0.011 & $-0.211\left(^{*}\right)$ & -0.147 & -0.040 & -0.060 \\
\hline & & 0.036 & 0.902 & 0.018 & 0.103 & 0.658 & 0.508 \\
\hline & $\begin{array}{l}\text { education_- } \\
\text { level_mother }\end{array}$ & $-0.245\left(^{* *}\right)$ & 0.002 & $-0.237(* *)$ & -0.078 & -0.083 & -0.058 \\
\hline & & 0.006 & 0.987 & 0.007 & 0.383 & 0.353 & 0.518 \\
\hline \multirow{2}{*}{ 氧葛 } & general_grade & -0.145 & $-0.199\left(^{*}\right)$ & $-0.213\left(^{*}\right)$ & -0.158 & $-0.459(* *)$ & $-0.266\left(^{* *}\right)$ \\
\hline & & 0.114 & 0.029 & 0.019 & 0.084 & 0.000 & 0.003 \\
\hline \multirow{2}{*}{ 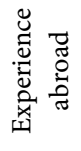 } & $\begin{array}{c}\text { travel_abroad } \\
\text { (for athletic reasons) }\end{array}$ & -0.017 & -0.057 & 0.030 & 0.055 & $-0.220\left(^{*}\right)$ & -0.039 \\
\hline & & 0.854 & 0.526 & 0.737 & 0.541 & 0.013 & 0.666 \\
\hline \multirow{4}{*}{ 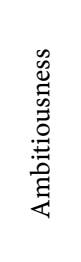 } & $\begin{array}{l}\text { desire for distinction } \\
\text { as a professional }\end{array}$ & $-0.190\left(^{*}\right)$ & $-0.250\left(^{* *}\right)$ & $-0.271\left(^{* *}\right)$ & $-0.205\left(^{*}\right)$ & -0.167 & -0.110 \\
\hline & & 0.033 & 0.005 & 0.002 & 0.021 & 0.062 & 0.220 \\
\hline & $\begin{array}{l}\text { desire for distinction } \\
\text { in science }\end{array}$ & $-0.192\left(^{*}\right)$ & -0.087 & $-0.197\left(^{*}\right)$ & $-0.223\left(^{*}\right)$ & 0.012 & -0.056 \\
\hline & & 0.031 & 0.331 & 0.027 & 0.012 & 0.890 & 0.533 \\
\hline \multirow{8}{*}{ 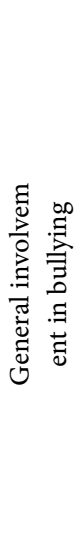 } & Havingexperienced & 0.095 & 0.145 & $0.180\left(^{*}\right)$ & -0.017 & 0.069 & 0.045 \\
\hline & & 0.289 & 0.106 & 0.044 & 0.852 & 0.441 & 0.614 \\
\hline & $\begin{array}{l}\text { Havingpracticed } \\
\text { cyberbullying }\end{array}$ & 0.111 & 0.138 & 0.174 & $0.210\left(^{*}\right)$ & 0.064 & 0.083 \\
\hline & & 0.218 & 0.123 & 0.051 & 0.018 & 0.477 & 0.358 \\
\hline & $\begin{array}{l}\text { having practiced } \\
\text { cyberbullying to other }\end{array}$ & 0.061 & $0.237\left(^{* *}\right)$ & 0.056 & 0.031 & 0.085 & 0.057 \\
\hline & & 0.500 & 0.007 & 0.532 & 0.730 & 0.343 & 0.530 \\
\hline & $\begin{array}{l}\text { having experienced } \\
\text { bullying as a child }\end{array}$ & -0.052 & $0.178\left(^{*}\right)$ & 0.065 & 0.020 & 0.030 & -0.038 \\
\hline & & 0.564 & 0.046 & 0.471 & 0.824 & 0.742 & 0.677 \\
\hline \multirow{6}{*}{ 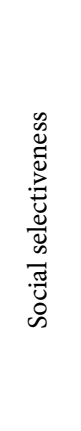 } & $\begin{array}{l}\text { selecting friends based } \\
\text { on encyclopedic } \\
\text { criteria }\end{array}$ & $-0.194\left(^{*}\right)$ & 0.003 & $-0.181\left(^{*}\right)$ & -0.155 & -0.072 & -0.074 \\
\hline & & 0.029 & 0.978 & 0.042 & 0.084 & 0.425 & 0.408 \\
\hline & $\begin{array}{l}\text { selecting friends based } \\
\text { on intelligence criteria }\end{array}$ & $-0.177\left(^{*}\right)$ & -0.090 & $-0.180\left(^{*}\right)$ & $-0.245(* *)$ & 0.016 & -0.040 \\
\hline & & 0.047 & 0.314 & 0.044 & 0.006 & 0.861 & 0.655 \\
\hline & $\begin{array}{l}\text { selecting friends based } \\
\text { on politeness criteria }\end{array}$ & -0.140 & $-0.204\left(^{*}\right)$ & -0.155 & -0.022 & -0.049 & -0.144 \\
\hline & & 0.118 & 0.022 & 0.084 & 0.807 & 0.587 & 0.107 \\
\hline
\end{tabular}

${ }^{*}$ Correlation is significant at the 0.01 level (2-tailed). ${ }^{*}$ Correlation is significant at the 0.05 level ( 2 -tailed). 
Table 7. Non-network determinants of practicing verbal aggressiveness.

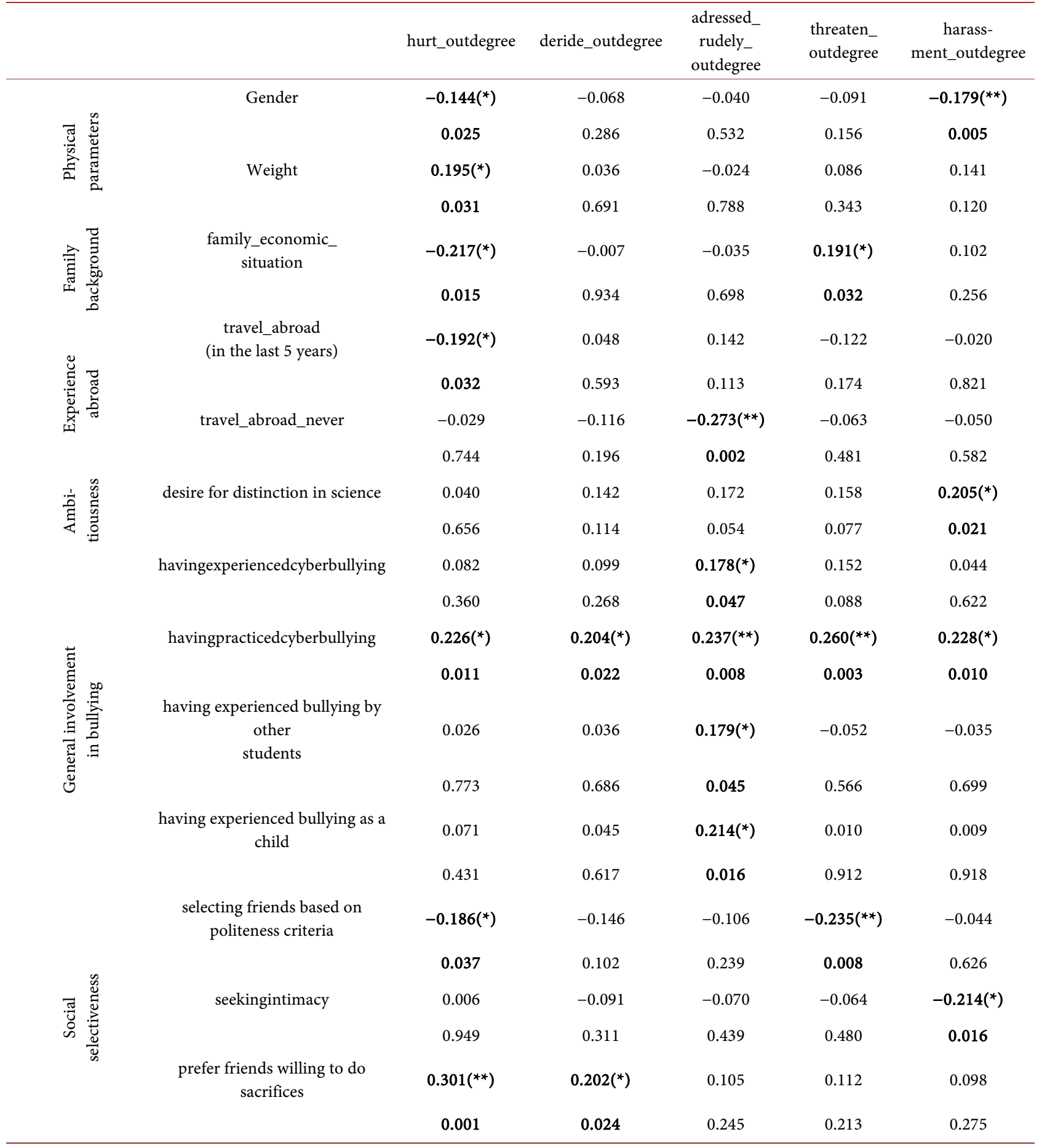

${ }^{*}$ Correlation is significant at the 0.01 level (2-tailed). ${ }^{*}$ Correlation is significant at the 0.05 level (2-tailed).

In "Table 8", the female students appear once again to avoid bullying behavior. On the contrary, as expected, heavy and tall students seem to be more susceptible to such behavior, as bullying directly necessitates corporal dominance.

As for the family background, the higher the education level of the father is, the more susceptible one becomes to bullying. This can be attributed to the self- 
Table 8. Non-network determinants of practicing bullying.

\begin{tabular}{|c|c|c|c|c|c|c|c|c|c|}
\hline & & $\begin{array}{l}\text { make_fun_- } \\
\text { outdegree }\end{array}$ & $\begin{array}{c}\text { unhappiness_ } \\
\text { outdegree }\end{array}$ & $\begin{array}{c}\text { exclude } \\
\text { outdedgree }\end{array}$ & $\begin{array}{c}\text { spread__ } \\
\text { rumors_- } \\
\text { outdegree }\end{array}$ & $\begin{array}{l}\text { fight__ } \\
\text { outdegree }\end{array}$ & $\begin{array}{c}\text { disagreements } \\
\text { outdegree }\end{array}$ & $\begin{array}{c}\text { encourage_ } \\
\text { to_scold_ } \\
\text { outdegree }\end{array}$ & $\begin{array}{c}\text { deny }_{-} \\
\text {help_outdegree }\end{array}$ \\
\hline \multirow{5}{*}{ 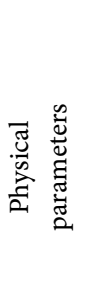 } & \multirow[t]{2}{*}{ Gender } & -0.053 & $-0.181(* *)$ & -0.119 & $-0.177(* *)$ & $-0.133\left(^{*}\right)$ & $-0.159\left(^{*}\right)$ & -0.097 & -0.115 \\
\hline & & 0.405 & 0.004 & 0.063 & 0.006 & 0.038 & 0.013 & 0.129 & 0.072 \\
\hline & \multirow[t]{2}{*}{ Height } & 0.062 & $0.195\left(^{*}\right)$ & 0.132 & 0.174 & $0.186\left(^{*}\right)$ & $0.243(* *)$ & 0.162 & 0.113 \\
\hline & & 0.495 & 0.030 & 0.141 & 0.053 & 0.037 & 0.006 & 0.071 & 0.210 \\
\hline & \multirow[t]{2}{*}{ Weight } & 0.050 & 0.155 & 0.054 & $0.211\left(^{*}\right)$ & 0.119 & $0.184\left(^{*}\right)$ & $0.308(* *)$ & 0.123 \\
\hline \multirow{4}{*}{ 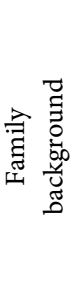 } & & 0.582 & 0.088 & 0.556 & 0.019 & 0.191 & 0.042 & 0.001 & 0.176 \\
\hline & $\begin{array}{l}\text { education_ } \\
\text { level_father }\end{array}$ & 0.122 & 0.091 & 0.054 & $0.181\left(^{*}\right)$ & 0.024 & 0.101 & 0.008 & 0.001 \\
\hline & & 0.175 & 0.313 & 0.547 & 0.043 & 0.792 & 0.264 & 0.932 & 0.993 \\
\hline & general_grade & 0.131 & -0.021 & 0.066 & 0.011 & 0.000 & -0.048 & $\left.-0.4422^{* *}\right)$ & -0.025 \\
\hline \multirow{4}{*}{ 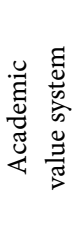 } & \multirow{3}{*}{ failedinexams } & 0.154 & 0.824 & 0.472 & 0.903 & 0.999 & 0.606 & 0.000 & 0.787 \\
\hline & & -0.151 & -0.069 & -0.062 & -0.070 & 0.029 & 0.064 & $\left.0.219^{*}\right)$ & 0.029 \\
\hline & & 0.097 & 0.452 & 0.499 & 0.446 & 0.751 & 0.483 & 0.016 & 0.749 \\
\hline & $\begin{array}{l}\text { apousia_- } \\
\text { apo_sxoleio }\end{array}$ & 0.061 & 0.137 & -0.023 & -0.049 & -0.096 & 0.070 & $0.178\left(^{*}\right)$ & -0.078 \\
\hline \multirow{3}{*}{ 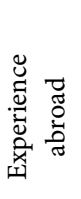 } & & 0.497 & 0.126 & 0.802 & 0.590 & 0.283 & 0.437 & 0.046 & 0.383 \\
\hline & $\begin{array}{c}\text { travel_abroad } \\
\text { (for athletic reasons) }\end{array}$ & -0.050 & -0.001 & -0.051 & -0.075 & 0.061 & -0.046 & $-0.212\left(^{*}\right)$ & 0.127 \\
\hline & & 0.581 & 0.990 & 0.571 & 0.405 & 0.496 & 0.606 & 0.017 & 0.158 \\
\hline \multirow{8}{*}{ 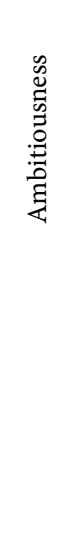 } & $\begin{array}{c}\text { Desire for distinction } \\
\text { as a professional }\end{array}$ & 0.074 & -0.067 & 0.001 & 0.013 & -0.070 & -0.013 & $-0.205\left(^{*}\right)$ & 0.097 \\
\hline & & 0.412 & 0.455 & 0.990 & 0.889 & 0.434 & 0.883 & 0.021 & 0.280 \\
\hline & $\begin{array}{l}\text { Desire for distinction } \\
\text { in science }\end{array}$ & 0.167 & -0.008 & $0.278\left(^{* *}\right)$ & 0.094 & 0.053 & 0.080 & 0.051 & 0.138 \\
\hline & & 0.061 & 0.929 & 0.002 & 0.294 & 0.553 & 0.372 & 0.569 & 0.122 \\
\hline & $\begin{array}{l}\text { Having experienced } \\
\text { cyber bullying }\end{array}$ & $0.176\left(^{*}\right)$ & -0.114 & 0.095 & 0.119 & $0.282(* *)$ & 0.152 & 0.163 & 0.024 \\
\hline & & 0.049 & 0.206 & 0.290 & 0.183 & 0.001 & 0.090 & 0.068 & 0.791 \\
\hline & $\begin{array}{l}\text { Having practiced } \\
\text { cyber bullying }\end{array}$ & $0.222\left(^{*}\right)$ & $0.203\left(^{*}\right)$ & 0.165 & $\left.0.297^{* *}\right)$ & $0.179\left(^{*}\right)$ & $0.276\left(^{* *}\right)$ & $0.267(* *)$ & 0.146 \\
\hline & & 0.013 & 0.023 & 0.065 & 0.001 & 0.045 & 0.002 & 0.003 & 0.103 \\
\hline \multirow{6}{*}{ 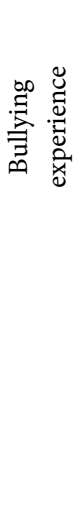 } & $\begin{array}{l}\text { Having experienced } \\
\text { bullying by other } \\
\text { students }\end{array}$ & $0.251\left(^{* *}\right)$ & 0.054 & 0.060 & -0.078 & -0.071 & 0.045 & -0.039 & 0.076 \\
\hline & & 0.005 & 0.546 & 0.502 & 0.384 & 0.427 & 0.618 & 0.666 & 0.397 \\
\hline & $\begin{array}{l}\text { Having practiced } \\
\text { cyber bullying to }\end{array}$ & 0.068 & $0.217\left(^{*}\right)$ & 0.104 & $0.341\left(^{* *}\right)$ & $0.265\left(^{* *}\right)$ & 0.053 & $0.253(* *)$ & $0.236\left(^{* *}\right)$ \\
\hline & & 0.450 & 0.015 & 0.245 & 0.000 & 0.003 & 0.559 & 0.004 & 0.008 \\
\hline & $\begin{array}{l}\text { Having experienced } \\
\text { bullying by students }\end{array}$ & $0.246\left(^{* *}\right)$ & -0.010 & 0.089 & 0.016 & 0.018 & 0.085 & 0.031 & 0.028 \\
\hline & & 0.005 & 0.914 & 0.322 & 0.859 & 0.844 & 0.342 & 0.733 & 0.752 \\
\hline
\end{tabular}




\section{Continued}

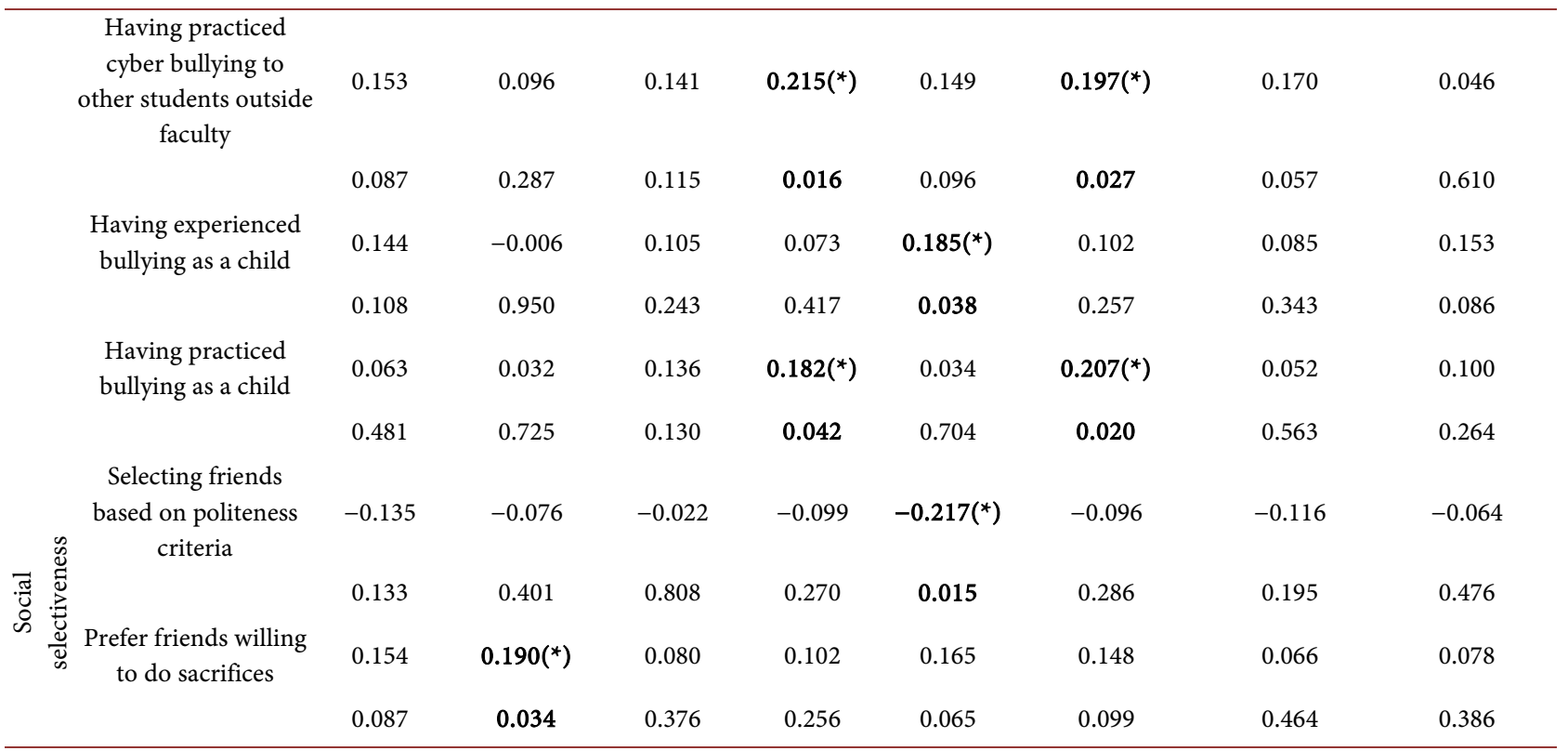

confidence one acquires by such a high family background encourages bullying to others.

The deeper the integration into the academic value system is, the more restricted the bullying is. Persons who are characterized by orderliness (high grade, restricted failing in the exams and attentiveness at the school) tend to avoid bullying. This shows that bullying is an effect of reaction against education system or a result of disintegration.

The travel experience seems to create a feeling of superiority and self-confidence which substitutes any tendency of imposing by bullying.

The role ambitiousness appears to be split into professional and scientific. Those who appear to be driven by professional ambitions tend to avoid practicing bullying. This is understandable, as they realize the necessity of being harmonically integrated into the society in order to be recognized as professionals. They understand that professional success does not depend only on the effectiveness but also, and perhaps more, on the sociability. On the contrary, those who desire distinction in scientific arena, seem to have adopted a quite peculiar or unsociable value system, driving them to bullying behavior. Not rarely, persons inspired by scientific values behave as dreamers who cannot tolerate the banal reality or the "inferior" persons who do not share similar values or antagonistic persons.

Practicing cyber-bullying is connected with simple bullying while having experienced bullying either as a childhood or as an adult is also correlated with the practicing of bullying. This shows that bullying tends to be generalized on every possible field of action. It also shows that it is a phenomenon characterized by diachronic reciprocity.

As expected, the social selectiveness according to the criterion of politeness appears once again to be a characteristic of those who avoid practicing bullying. 
On the other hand, those who are susceptible to bullying behavior tend to prefer persons willing to make sacrifices for companion, as these are supposed to tolerate also their bullying. In part similar and extensive determinants have been explored in previous research [67] [68] [71].

\section{Conclusions}

Anomalous pyramids (several summits) of rudeness targeting appear in the department of Physical Education as a result of the subject of this department (sport-related competition and pressure lead to sporadic and multiple outbursts). Moreover, rudeness relations are denser at the Physical Education department than at the other two departments (Veterinary and Business Administration) also due to the intensity and pressure of corporal exercise. Social exclusion seems not to depend on the subject of the department but rather on the common mentality characterizing all students.

Hurting necessitates particularly intensive conditions while deriding, rudeness and threatening are compatible with any action of bullying. Exclusion, fight, scolding and denying help are not so harassing while rumors dissemination, disagreements, targeting for fun and unhappiness are conducive for harassment. While the targets seem to attract particular combinations of bullying and verbal aggression, these two behavioral patterns seem to be practiced by each offender quite simultaneously. The offenders tend to practice simultaneously bullying and verbal aggressiveness but often against different targets.

The types of targeting reveal various behavioral patterns ranging from quite generalized to quite selective strategy of aggressiveness and bullying (from "fully offended" to "just excluded"). Thus, various levels of victimization are diagnosed through this selectiveness. As for the types of offenders, the grade of offensiveness seems also to be a matter of selectiveness in strategies.

Concerning the non-network variables, they appear to be determinants for being targeted of verbal aggressiveness and bullying. Obesity often constitutes a reason of depreciation. High academic performance and education values seem to stimulate respectfulness rather than aggressive jealousness and thereby to play a protective role. Moreover, older students are more respected by the others. Ambitiousness and travelling experience seem also to be respected. Social selectiveness based on criteria of intellectual and encyclopedic qualifications or politeness also prevents verbal aggressiveness. On the contrary, those who select for friends such persons who are willing to make sacrifices are susceptible to verbal aggressiveness.

Female students seem to be more invulnerable. The general involvement in bullying, being a target of but also practicing cyber bullying seems to constitute someone a target of direct bullying. This reveals bullying's reciprocity. There seems also to be a common perception of bullying among victims and victimizers. Additionally, bullying seems to be a diachronic pattern of social action on the same person, from nonage to adultness.

Verbal aggressiveness seems to conceal a presumption of corporal aggressive- 
ness. Students originating from rich families are not used to practicing severe forms of verbal aggressiveness but they desire to enhance their dominance or defense toward others (classical gap between "theory and practice"). Especially, ambitiousness in the scientific arena or the high education level of father seems to encourage practicing verbal aggressiveness, as they induce feeling of social superiority and self-confidence or obsessive perfectionism and unsociability.

Limitations of this research and respective challenges for further research are that more parameters could have been examined on larger sample, achieving an insightful comparison. Points for future research could be to extract more extensive and detailed typologies of aggressive and bullying patterns and, of course, to extend the sampling to a wider range of Higher Education departments and various milieus. Comparing these different departments or milieus will also produce interesting results. Examining more non-network variables as possible determinants would also be expected to deepen the awareness of how aggressiveness and bullying function. The more insightful exploration of the diachronic and reciprocal character of bullying constitutes an additional research challenge.

An operational pedagogic suggestion for avoiding verbal aggressiveness and bullying is the meticulous selection of companion, the academic self-improvement, the cultivation of ambitiousness (especially professional ambitions) and the development of personality by acquiring experience abroad. Apart from that, the bullying background or the cyber bullying should also be taken into consideration in order to draw attention to persons who possibly are susceptible to bullying.

\section{References}

[1] Olweus, D. (1997) Bully/Victim Problems in School: Facts and Intervention. European Journal of Psychology of Education, 12, 495-510. https://doi.org/10.1007/BF03172807

[2] Olweus, D. (2013) School Bullying: Development and Some Important Challenges. Annual Review of Clinical Psychology, 9, 751-780. https://doi.org/10.1146/annurev-clinpsy-050212-185516

[3] Olweus, D. (1993) Bullying at School: What We Know and What We Can Do (Understanding Children's Worlds). Blackwell Publishing, Oxford.

[4] McMahon, L. (2000) Bullying and Harassment in the Workplace. International Journal of Contemporary Hospitality Management, 12, 384-387. https://doi.org/10.1108/09596110010343666

[5] Einarsen, S. and Skogstad, A. (1996) Bullying at Work: Epidemiological Findings in Public and Private Organizations. European Journal of Work and Organizational Psychology, 5, 185-201. https://doi.org/10.1080/13594329608414854

[6] Ringrose, J. and Renold, E. (2010) Normative Cruelties and Gender Deviants: The Performative Effects of Bully Discourses for Girl and Boys in School. British Educational Research Journal, 36, 573-596. https://doi.org/10.1080/01411920903018117

[7] McKay, R., Huberman, A.D. and Fratzl, J. (2008) Workplace Bullying in Academia: A Canadian Study. Employee Responsibilities and Rights Journal, 20, 77-100. https://doi.org/10.1007/s10672-008-9073-3

[8] Taylor, S. (2013) Workplace Bullying: Does Tenure Change Anything? The Exam- 
ple of a Midwestern Research University. In: Lester, J., Ed., Workplace Bullying in Higher Education, Routledge, Florence, 23-40.

[9] Twale, D.J. and De Luca, B.M. (2008) Faculty Incivility: The Rise of the Academic Bully Culture and What to Do about It. John Wiley \& Sons, San Francisco.

[10] Olweus, D. (1991) Bully/Victim Problems among Schoolchildren: Basic Facts and Effects of a School Based Intervention Program. In: Pepler, D. and Rubin, K., Eds., The Development and Treatment of Childhood Aggression, Erlbaum, Hillsdale, 411-448.

[11] Lewis, D. (2010) Bullying at Work: The Impact of Shame among University and College Lecturers. British Journal of Guidance \& Counselling, 32, 281-299. https://doi.org/10.1080/03069880410001723521

[12] Zabrodska, K., Ellwood, C. and Zaeemdar, S. (2014) Workplace Bullying as SenseMaking: An Analysis of Target and Actor Perspectives on Initial Hostile Interactions. Culture and Organization, 22, 136-157. https://doi.org/10.1080/14759551.2014.894514

[13] Ireland, J.L. (2000) "Bullying” among Prisoners: A Review of Research. Aggression and Violent, 5, 201-215. http://psycnet.apa.org/doi/10.1016/S1359-1789(98)00031-7

[14] Boulton, M.J. and Underwood, K. (1992) Bully/Victim Problems among Middle School Children. British Journal of Educational Psychology, 62, 73-87. https://doi.org/10.1111/j.2044-8279.1992.tb01000.x

[15] Kochenderfer, B.J. and Ladd, G.W. (1996) Peer Victimization: Cause or Consequence of School Maladjustment. Child Development, 67, 1305-1317. https://doi.org/10.2307/1131701

[16] Harris, S. and Petrie, G. (2003) Bullying. The Bullies, the Victims, the Bystanders. Lanham, MD and Oxford: Scarecrow.

[17] Bowers, L., Smith, P.K. and Binney, V. (1994) Perceived Family Relationships of Bullies, Victims and Bully/Victims in Middle Childhood. Journal of Social and Personal Relationships, 11, 215-232. https://doi.org/10.1177/0265407594112004

[18] Rutter, M. (1995) Psychosocial Disturbances in Young People: Challenges for Prevention. New York, NY: Hambridge University Press.

[19] Craig, W.M. (1998) The Relationship among Bullying, Victimization, Depression, Anxiety and Aggression in Elementary School Children. Personality and Individual Differences, 24, 123-130.

[20] Kumpulainen, K., Räsänen, E. and Henttonen, I. (1999) Children Involved in Bullying: Psychological Disturbance and Persistence of the Involvement. Child Abuse and Neglect, 23, 1253-1262.

[21] Peterson, R.L. and Skiba, R. (2001) Creating School Climate That Prevent School Violence. Clearing House, 74, 155-163. https://doi.org/10.1080/00098650109599183

[22] Rigby, K. and Slee, P.T. (1999) Australia. In: Smith P.K., Morita Y., Junger-Tas J., Olweus D., Catalano R. and Slee P., Eds., The Nature of School Bullying. A CrossNational Perspective, Routledge, New York, 324-339.

[23] Greenbaum, S. (1989) Set Straight on Bullies. ERIC Document Reproduction No. ED-312744, National School Safety Center.

[24] Infante, D.A. and Wigley III, C.J. (1986) Verbal Aggressiveness: An Interpersonal Model and Measure. Communication Monographs, 53, 61-69. https://doi.org/10.1080/03637758609376126

[25] Infante, D.A. (1987) Aggressiveness. In: McCroskey, J.C. and Daly, J.A., Eds., Personality and Interpersonal Communication, Sage, Newbury Park, 157-192.

[26] Infante, D.A., Sabourin, T.C., Rudd, J.E. and Shannon, E.A. (1990) Verbal Aggres- 
sion in Violent and Nonviolent Marital Disputes. Communication Quarterly, 38, 361-371. https://doi.org/10.1080/01463379009369773

[27] Bekiari, A. and Sakellariou, K. (2003) Perceived Instructor Verbal Aggressiveness and Student State Learning in Physical Education. Italian Journal of Sport Sciences, 1, 251-256.

[28] Bekiari, A., Koustelios, A. and Sakellariou, K. (2000) Instructors' Verbal Aggressiveness from Universities in Greece. Studi e Ricerche, 5, 225-232.

[29] Bekiari, A., Digelidis, N. and Sakellariou, K. (2006) Perceived Verbal Aggressiveness of Coaches in Volleyball and Basketball: A Preliminary Study. Psychological Reports, 103, 526-530.

[30] Rancer, A.S. and Avtgis, T.A. (2014) Argumentative and Aggressive Communication. 2nd Edition, Peter Lang, New York.

[31] Infante, D.A. and Rancer, A.S. (1996) Argumentativeness and Verbal Aggressiveness: A Review of Recent Theory and Research. Communication Yearbook, 19, 319 351. https://doi.org/10.1080/23808985.1996.11678934

[32] An, Y.A., Kim, B.S. and Kim, J.C. (2014) The Relationships of between College Students' Narcissism and Aggressiveness: The Moderating Effects of Self-Esteem, Stability of Self-Esteem, Self-Concept Clarity. Korea Journal of Counseling, 15, 24512470. https://doi.org/10.15703/kjc.15.6.201412.2451

[33] Bekiari, A. (2016) Insights into Instructors' Verbal Aggressiveness and Students' Machiavellianism through Leadership Style and Motivational Climate. European Scientific Journal, 12, 90-110. https://doi.org/10.19044/esj.2016.v12n25p90

[34] Bekiari, A. (2017) Exploring Relations between Instructors' Verbal Aggressiveness and Argumentativeness and Students' Fair Play Behaviours and Machiavellianism. International Journal of Physical Education, 54.

[35] Bekiari, A. (2014) Verbal Aggressiveness and Leadership Style of Sports Instructors and their Relationship with Athletes' Intrinsic Motivation. Creative Education, 5, 114-121. https://doi.org/10.4236/ce.2014.52018

[36] Bekiari, A., Patsiaouras, A., Kokaridas, D. and Sakellariou, K. (2006) Verbal Aggressiveness and State Anxiety of Volleyball Players and Coaches. Psychological Reports, 99, 630-634.

[37] Bekiari, A. (2012) Perceptions of Instructors' Verbal Aggressiveness and Physical Education Students' Affective Learning. Perceptual and Motor Skills, 115, 325-335. https://doi.org/10.2466/06.11.16.PMS.115.4.325-335

[38] Bekiari, A. and Manoli, P. (2016) EFL Teacher Verbal Aggressiveness and Argumentativeness and Student Socio-Affective Strategy Use and Affective Learning: Exploring Possible Associations. Journal of Teacher Education and Educators, 5, 154-171.

[39] Bekiari, A. and Tsaggopoulou, Th. (2016) Verbal Aggressiveness and Affective Learning in Physical Education. Advances in Physical Education, 6, 406-418. https://doi.org/10.4236/ape.2016.64041

[40] Bekiari, A. and Spyropoulou, S. (2016) Exploration of Verbal Aggressiveness and Interpersonal Attraction through Social Network Analysis: Using University Physical Education Class as an Illustration. Open Journal of Social Sciences, 4, 145-155. https://doi.org/10.4236/jss.2016.46016

[41] Syrmpas, I. and Bekiari, A. (2015) The Relationship between Perceived Physical Education Teacher's Verbal Aggressiveness and Argumentativeness with Students' Interpersonal Attraction. Inquiries in Sport \& Physical Education, 13, 21-32.

[42] Bekiari, A. and Petanidis, D. (2016) Exploring Teachers' Verbal Aggressiveness 
through Interpersonal Attraction and Students' Intrinsic Motivation. Open Journal of Social Sciences, 4, 72-85. https://doi.org/10.4236/jss.2016.412007

[43] Bekiari, A. and Tsiana, I. (2016) Exploring Instructors' Verbal Aggressiveness and Students' Personal Orientations and Reasons of Discipline in Physical Education Class. Advances in Physical Education, 6, 158-168.

https://doi.org/10.4236/ape.2016.63018

[44] Manoli, P. and Bekiari, A. (2015) EFL Teachers' Verbal Aggressiveness and Students' Intrinsic Motivation and Social-Affective Strategy Use: Investigating Possible Relations. Advances in Research, 5, 1-13. https://doi.org/10.9734/AIR/2015/19692

[45] Bekiari, A., Kokaridas, D. and Sakellariou, K. (2005) Verbal Aggressiveness of Physical Education Teachers and Students' Self-Reports of Behaviour. Psychological Reports, 96, 493-498. https://doi.org/10.2466/pr0.96.2.493-498

[46] Bekiari, A., Kokaridas, D. and Sakellariou, K. (2006) Associations of Students' SelfReports of Their Teacher's Verbal Aggression, Intrinsic Motivation, and Perceptions of Reasons for Discipline in Greek Physical Education Classes. Psychological Reports, 98, 451-461. https://doi.org/10.2466/pr0.98.2.451-461

[47] Bekiari, A., Perkos, S. and Gerodimos, V. (2015) Verbal Aggression in Basketball: Perceived Coach Use and Athlete Intrinsic and Extrinsic Motivation. Journal of Physical Education and Sport, 15, 96-102.

[48] Bekiari, A. and Pylarinou, M. (2016) Instructor Argumentativeness and Socio-Communicative Style and Student Discipline: Using Physical Education Students' Class as an Illustration. Open Journal of Social Sciences, 5, 122-136. https://doi.org/10.4236/jss.2017.53011

[49] Bekiari, A. and Syrmpas, I. (2015) Coaches' Verbal Aggressiveness and Motivational Climate as Predictors of Athletes' Satisfaction. British Journal of Education, Society \& Behavioural Science, 9, 318-329. https://doi.org/10.9734/BJESBS/2015/17757

[50] Hassandra, M., Bekiari, A. and Sakellariou, K. (2007) Physical Education Teacher's Verbal Aggression and Student's Fair Play Behaviors. The Physical Educator, 64, 94-101.

[51] Edwards, C. and Myers, S.A. (2007) Perceived Instructor Credibility as a Function of Instructor Aggressive Communication. Communication Research Reports, 24, 47-53. https://doi.org/10.1080/08824090601128141

[52] Schrodt, P. (2003) Students' Appraisals of Instructors as a Function of Students' Perceptions of Instructors' Aggressive Communication. Communication Education, 52, 106-121. https://doi.org/10.1080/03634520302468

[53] Anitei, M., Chraif, M.A., Verde, V.B. and Mihaila, T. (2014) The Big Five Personality Factors in the Prediction of Aggressive Driving Behavior among Romanian Youngsters. International Journal of Traffic and Transportation Psychology, 2.

[54] Anderson, C.M. and Martin, M.M. (1999) The Relationship of Argumentativeness and Verbal Aggressiveness to Cohesion, Consensus, and Satisfaction in Small Groups. Communication Reports, 12, 21-31. https://doi.org/10.1080/08934219909367705

[55] Wigman, S.A., Graham-Kevan, N. and Archer, J. (2008) Investigating Sub-Groups of Harassers: The Roles of Attachment, Dependency, Jealousy and Aggression. Journal of Family Violence, 23, 557-568. https://doi.org/10.1007/s10896-008-9171-x

[56] Bekiari, A., Deliligka, S. and Hasanagas, N. (2017) Analysing Networks of Verbal Aggressiveness and Motivation. Psychology, 8, 495-515. https://doi.org/10.4236/psych.2017.83031

[57] Bekiari, A., Pachi, V. and Hasanagas, N. (2017) Investigating Bullying Determinants 
and Typologies with Social Network Analysis. Journal of Computer and Communications, 5, 11-27. https://doi.org/10.4236/jcc.2017.57002

[58] Bekiari, A. and Hasanagas, N. (2016) Sociological Insights in the Education System: "Unlocking" the Power Relations. Afoi Kyriakidi Editions S.A., Thessaloniki.

[59] Bekiari, A. and Hasanagas, N. (2016) "Educating” in Physical Education. Theoretical Approaches and Practical Inquiries. Afoi Kyriakidi Editions S.A., Thessaloniki.

[60] Bekiari, A. and Hasanagas, N. (2016) Suggesting Indicators of Superficiality and Purity in Verbal Aggressiveness. An Application in Adult Education Class Networks of Prisoners. Open Journal of Social Sciences, 4, 279-292. https://doi.org/10.4236/jss.2016.43035

[61] Theoharis, D. and Bekiari, A. (2017) Applying Social Network Indicators in the Analysis of Verbal Aggressiveness at the School. Journal of Computer and Communications, 5, 169-181.

[62] Theoharis, D. and Bekiari, A. (2017) Cumulative Hierarchy Analysis (Katz Centrality) on Leadership Networks of Learning Communities. Proceedings of the 9 th International Congress Mathematical Society, Thessaloniki, 17-19 March 2017, 285297.

[63] Theoharis, D. and Bekiari, A. (2016) The Influence of Mathematics and Learning Environment in Verbal Aggressiveness and Interpersonal Relations: A Dynamic Analysis of Social Networks. Proceedings of the 8 th International Congress Mathematical Society, Thessaloniki, 30 March-3 April 2016, 415-428.

[64] Theoharis, D. and Bekiari, A. (2016) Social Networks Analysis of Centrality: Case Study in Leadership Networks. Proceedings of the 33 rd Congress Greek Mathematical Society with International Participation, Chania, 4-6 November 2016, 250-260.

[65] Bekiari, A. and Hasanagas, N. (2015) Verbal Aggressiveness Exploration through Complete Social Network Analysis: Using Physical Education Students' Class as an Illustration. International Journal of Social Science Studies, 3, 30-49. https://doi.org/10.11114/ijsss.v3i3.729

[66] Bekiari, A. and Digelidis, N. (2015) Measuring Verbal Aggressiveness in Sport and Education. International Journal of Physical Education, 52, 12-21.

[67] Hasanagas, N. and Bekiari, A. (2015) Depicting Determinants and Effects of Intimacy and Verbal Aggressiveness Target through Social Network Analysis. Sociology Mind, 5, 162-175. https://doi.org/10.4236/sm.2015.53015

[68] Hasanagas, N. and Bekiari, A. (2017) An Exploration of the Relation between Hunting and Aggressiveness: Using Inmates Networks at Prison Secondary School as an Illustration. Social Networking, 6, 19-37. https://doi.org/10.4236/sn.2017.61002

[69] Bekiari, A., Nikolaidou, Z. and Hasanagas, N. (2017) Typology of Motivation and Aggression on the Basis of Social Network Variables: Examples of Complementary and Nested Behavioral Types through Conventional Statistics. Social Networking, 6, 135-147. https://doi.org/10.4236/sn.2017.62008

[70] Theoharis, D., Bekiari, A. and Koustelios, A. (2017) Exploration of Determinants of Verbal Aggressiveness and Leadership through Network Analysis and Conventional Statistics. Using School Class as an Illustration. Sociology Mind, 7, 27-43. https://doi.org/10.4236/sm.2017.72003

[71] Bekiari, A., Deliligka, S. and Koustelios, A. (2016) Examining Relations of Aggressive Communication in Social Networks. Social Networking, 6, 38. https://doi.org/10.4236/sn.2017.61003

[72] Bekiari, A., Hasanagas, N., Theoharis, D., Kefalas, I. and Vasilou, A. (2015) The 
Role of Mathematical Object and the Educational Environment to Students' Interpersonal Relationships: An Application of Full Social Network Analysis. Proceedings of the 32 nd Congress Greek Mathematical Society with International Participation, Kastoria, 799-812.

[73] Bekiari, A. and Balla, K. (2017) Instructors and Students Relations: Argumentativeness, Leadership and Goal Orientations. Open Journal of Social Sciences.

Submit or recommend next manuscript to SCIRP and we will provide best service for you:

Accepting pre-submission inquiries through Email, Facebook, LinkedIn, Twitter, etc. A wide selection of journals (inclusive of 9 subjects, more than 200 journals)

Providing 24-hour high-quality service

User-friendly online submission system

Fair and swift peer-review system

Efficient typesetting and proofreading procedure

Display of the result of downloads and visits, as well as the number of cited articles

Maximum dissemination of your research work

Submit your manuscript at: http://papersubmission.scirp.org/

Or contact jcc@scirp.org 